\title{
Analisis Video Comments to Image Comments Ratio Instagram Pada 6 Penyanyi Indonesia yang Sukses Sebagai Pemain Film
}

\author{
I Kadek Sandratiana \\ ikadeksandratiana@gmail.com
}

\begin{abstract}
One of the information and communication technologies that are increasingly being used today is the Instagram social network. Instagram has more than 1 billion active users per month. Instagram is a relatively new form of communication where users can easily share information in the form of photos or videos known as "updates". The large number of active Instagram users in Indonesia can certainly provide opportunities for celebrities to turn this platform into a social media entertainment and business platform. There are 6 Indonesian singers who are successful as film players who use the Instagram platform as a social media entertainment and business platform, including: Maudy Ayunda, Iqbaal Ramadhan, Bunga Citra Lestari, Morgan Oey, Cinta Laura, and Isyana Sarasvati. The purpose of this study is to calculate the credibility of the Instagram account performance of Top 6 Successful Indonesian Singers as Film Players. This study uses quantitative methods and calculates using the ratios on Instagram. The results of this study indicate that a successful Indonesian singer as a film player, namely Cinta Laura, is ranked first and has good account performance credibility.
\end{abstract}

\begin{abstract}
ABSTRAK
Salah satu teknologi informasi dan komunikasi yang semakin banyak digunakan saat ini adalah jejaring sosial Instagram. Instagram memiliki lebih dari 1 miliyar pengguna aktif perbulannya. Instagram adalah bentuk komunikasi yang relatif baru di mana pengguna dapat dengan mudah berbagi informasi dalam bentuk foto atau video yang dikenal sebagai "pembaruan". Banyaknya jumlah pengguna Instagram yang aktif di Indonesia tentunya dapat memberikan peluang bagi para selebrity untuk mengubah platform ini sebagai platform sosial media entertainment dan bisnisnya. Adapun 6 penyanyi Indonesia yang sukses sebagai pemain film yang memanfaatkan platform Instagram sebagai platform sosial media entertainment dan bisnis, diantaranya yaitu: Maudy Ayunda, Iqbaal Ramadhan, Bunga Citra Lestari, Morgan Oey, Cinta Laura, dan Isyana Sarasvati. Tujuan dari penelitian ini adalah untuk menghitung kredibilitas dari performa akun Instagram Top 6 Penyanyi Indonesia yang Sukses sebagai Pemain Film. Penelitian ini menggunakan metode kuantitatif dan menghitung menggunakan rasio yang ada di Instagram. Hasil dari penelitian ini menunjukan bahwa penyanyi Indonesia yang sukses sebagai pemain film yaitu Cinta Laura yang mendapatkan peringkat pertama dan memiliki kredibilitas performa akun yang baik.
\end{abstract}


Keyword : Rasio Akun Instagram ; Video Comments to Image Comments Ratio ; Sosial Media Entertainment dan Bisnis ; Penyanyi Indonesia Sukses sebagai Pemain Film.

\section{PENDAHULUAN}

Perkembangan teknologi informasi dan komunikasi mengalami kemajuan yang sangat pesat, membawa perubahan dalam tatanan kehidupan sosial manusia termasuk pola komunikasi, sehingga manusia tidak lagi terkendala jarak, batas, ruang, dan waktu dalam berkomunikasi. Kemajuan teknologi informasi dan komunikasi juga telah menciptakan "dunia dalam genggaman". Istilah tersebut merupakan gambaran dari ungkapan Thomas L. Friedman yang dikutip oleh Nasrullah (2015), the world is flat yaitu keadaan dunia yang semakin rata karena setiap orang dapat mengakses informasi apa pun melalui internet (Permassanty and Muntiani 2018).

Dengan adanya teknologi informasi dan komunikasi seperti saat ini, kebutuhan informasi masyarakat menjadi semakin mudah. Salah satu teknologi informasi dan komunikasi yang semakin banyak digunakan saat ini adalah jejaring sosial Instagram. Instagram memiliki lebih dari 1 miliyar pengguna aktif perbulannya (Koltay 2019). Instagram adalah bentuk komunikasi yang relatif baru di mana pengguna dapat dengan mudah berbagi informasi dalam bentuk foto atau video yang dikenal sebagai "pembaruan". Aplikasi Instagram yang mudah digunakan memungkinkan pengguna untuk mengubah Instagram menjadi media komunikasi yang memenuhi kebutuhan masyarakat. Penggunaan Instagram sebagai media edukasi merupakan fenomena baru dalam penggunaan jejaring sosial, meskipun jejaring sosial terus berkembang dan sangat populer di kalangan anak muda saat ini (Sari and Basit 2020).

Banyaknya jumlah pengguna Instagram yang aktif di Indonesia tentunya dapat memberikan peluang bagi para selebrity untuk mengubah platform ini sebagai platform sosial media entertainment dan bisnisnya. Cukup maraknya akun selebrity terkenal yang ada pada Instagram, contohnya seperti penyanyi Indonesia yang sukses sebagai pemain film. Adapun 6 Penyanyi Indonesia yang Sukses sebagai Pemain Film, diantaranya yaitu: Maudy Ayunda, Iqbaal Ramadhan, Bunga Citra Lestari, Morgan Oey, Cinta Laura, dan Isyana Sarasvati ("Multitalenta, 6 Penyanyi Indonesia Yang Sukses Sebagai Pemain Film” n.d.).

Penelitian ini menggunakan metode kuantitatif dan menghitung menggunakan rasio yang ada di Instagram. Pada penelitian (Hendika Permana 2021) menjelaskan bahwa terdapat ada 14 rasio di sosial media Instagram dan relevan digunakan sebagai media ukur kredibilitas akun yang ada. Penelitian ini hanya berfokus untuk menghitung kredibilitas Video Comments to Image Comments Ratio pada 6 Penyanyi Indonesia yang Sukses sebagai Pemain Film. Adapun 6 Penyanyi Indonesia yang Sukses sebagai Pemain Film, diantaranya yaitu: Maudy Ayunda, Iqbaal Ramadhan, Bunga Citra Lestari, Morgan Oey, Cinta Laura, dan Isyana Sarasvati (“6 Penyanyi Indonesia yang Sukses Sebagai Pemain Film - idntimes.com”). Tujuan dari penelitian ini adalah mengetahui kredibilitas performa dari akun Instagram 6 Penyanyi Indonesia yang Sukses sebagai Pemain Film menggunakan Video Comments to Image Comments Ratio. 


\section{TINJAUAN PUSTAKA}

Perubahan zaman membawa banyak perkembangan. Salah satunya adalah munculnya new media, yang merupakan salah satu bentuk perkembangan di dunia media sosial. New media adalah media yang menggunakan internet, sebuah media online berbasis teknologi yang bersifat fleksibel, berpotensi untuk berinteraksi, dan dapat beroperasi baik di sektor private maupun publik (Norhabiba and Ragil 2018). Selain untuk berinteraksi, masyarakat dapat menggunakan new media untuk hiburan, ekspresi diri, dan bisnis. Hal tersebut dapat ditemukan di new media sosial. Contohnya adalah adanya akun dengan postingan berisi konten hiburan atau bisnis di salah satu platform new media sosial yaitu Instagram. Jadi, dengan menggunakan new media sosial ini, orang yang membutuhkan hiburan atau bisnis dapat mengaksesnya dengan mudah tanpa harus mengeluarkan banyak biaya (Syahadatina 2018).

Instagram adalah aplikasi untuk berbagi foto dan video. Instagram sendiri masih merupakan bagian dari Facebook, memungkinkan teman-teman Facebook untuk mengikuti di akun media sosial Instagram kita. Popularitas Instagram yang semakin meningkat sebagai aplikasi untuk berbagi foto dan video membuat banyak pengguna terjun ke dunia bisnis atau hiburan, seperti akun sosial perusahaan yang juga mempromosikan produknya dan banyaknya dunia hiburan melalui Instagram(Shafita 2018).

Instagram memiliki banyak pengguna karena kemudahan dan kecepatan dalam berbagai banyak foto dan video bergaya retro yang menarik. Pengguna dapat menikmati 17 filter foto yang mengubah warna dan menciptakan nuansa foto yang berbeda. Instagram menawarkan cara baru untuk berkomunikasi di jejaring sosial melalui foto dan video. Konsep jejaring sosial dengan foto "follow", "like" dan "populer" membuat Instagram semakin banyak penggunanya. Semakin banyak pengguna smartphone yang suka berfoto. Tetapi tujuan membuat Instagram bukan hanya aplikasi foto, tetapi cara baru untuk berkomunikasi melalui gambar dan jenis komunikasi yang berbeda. Karena aplikasi pengolah gambar adalah sebuah alat (Difika 2016).

Karakteristik dan keunikan Instagram adalah hanya berisi aliran karya fotografi dari para penggunanya. Fitur utamanya mirip dengan Twitter, mulai dari penggunaan istilah "pengikut" untuk akun yang saling bertautan satu sama lain, sampai ke fitur @mention dan \#hastag. Meskipun Twitter sudah menerapkan fitur berbagi foto dan video yang berfokus terutama pada pengembangan produk, Instagram masih menjadi platform fotografi jaringan yang dominan. Dominasi Instagram sekali lagi menjadi ajang produk ini khusus didedikasikan untuk membangun hubungan digital melalui karya fotografi (Ii, Teori, and Pemasaran 2017).

Instagram dipandang memiliki kekuatan atau pengaruh dalam industri, sehingga menghasilkan kualitas akun yang menentukan strata dan kredibilitas pemilik akun. Kredibilitas akun Instagram cukup penting untuk berbagai keperluan. Kredibilitas akun Instagram dapat diukur dengan tingkat kinerja yang dihasilkan secara matematis. Untuk mengukur kinerja kredibilitas pemilik akun, skala harus dimasukkan dalam laporan menggunakan rasio yang ada di Instagram. 


\section{METODE PENELITIAN}

Penelitian ini dilakukan untuk mengidentifikasi keandalan/kredibilitas akun Instagram 6 Penyanyi Indonesia Yang Sukses Sebagai Pemain Film dengan menggunakan metode eksploratif kuantitatif. Penelitian eksploratif adalah penelitian yang bertujuan untuk memperdalam pengetahuan dan menemukan ide-ide baru tentang suatu fenomena tertentu, menggambarkan fenomena sosial dan menjelaskan bagaimana suatu fenomena sosial terjadi untuk membentuk masalah secara lebih rinci atau mengembangkan hipotesis alternatif untuk menguji hipotesis. Penelitian eksploratif merumuskan pertanyaan penelitian yang lebih relevan sehingga hasil penelitian deskriptif dan eksplanatif selanjutnya dapat menjawab pertanyaan lain yang akan muncul di masa yang akan datang (Mudjiyanto 2018).

Adapun tujuan dari penelitian ini adalah untuk mengetahui nilai keandalan/kredibilitas kinerja pada akun Instagram 6 Penyanyi Indonesia Yang Sukses Sebagai Pemain Film. Ada beberapa langkah yang patut dilakukan untuk penelitian ini, agar bisa menemukan akun Instagram peringkat pertama dari 6 Penyanyi Indonesia Yang Sukses Sebagai Pemain Film yang mempunyai keandalan/kredibilitas kinerja terbaik. Berikut langkah-langkah yang dilakukan dalam penelitian ini:

\section{Melakukan Eksplorasi Pada Website Untuk Menentukan Objek yang Akan Dianalisa.}

Eksplorasi ini dilakukan pada sejumlah beberapa website yang menyediakan informasi tentang objek yang akan di teliti. Setelah selesai melakukan ekslorasi, maka akan ditemukan nama-nama penyanyi Indonesia, sehingga bisa dijadikan objek analisa. Untuk melakukan eksplorasi pada halaman website, maka langkah selanjutnya adalah mencari nama akun Instagram dari masing-masing penyanyi Indonesia yang sukses sebagai pemain film. Pastikan semua penyanyi Indonesia memiliki akun pada aplikasi sosial media Instagram.

\section{Menghitung Nilai Rata-Rata Variable Dari Top 6 Penyanyi Indonesia Yang Sukses Sebagai Pemain Film.}

Pada langkah ini, peneliti menghitung nilai variable video comments dan variable image comments. Variabel adalah sesuatu yang memiliki nilai variabel dimana nilai tersebut dapat dijadikan dasar untuk 4 data yang berbeda seperti rate, ratio, ordinal, nominal dan internal (Dahri 2019). Untuk menghitung nilai rata-rata dari variabel video comments dan variabel image comments adalah dengan cara mengambil minimal 10 postingan, setelah itu di hitung sehingga menemukan nilai rata-rata dari masing-masing variabel. 


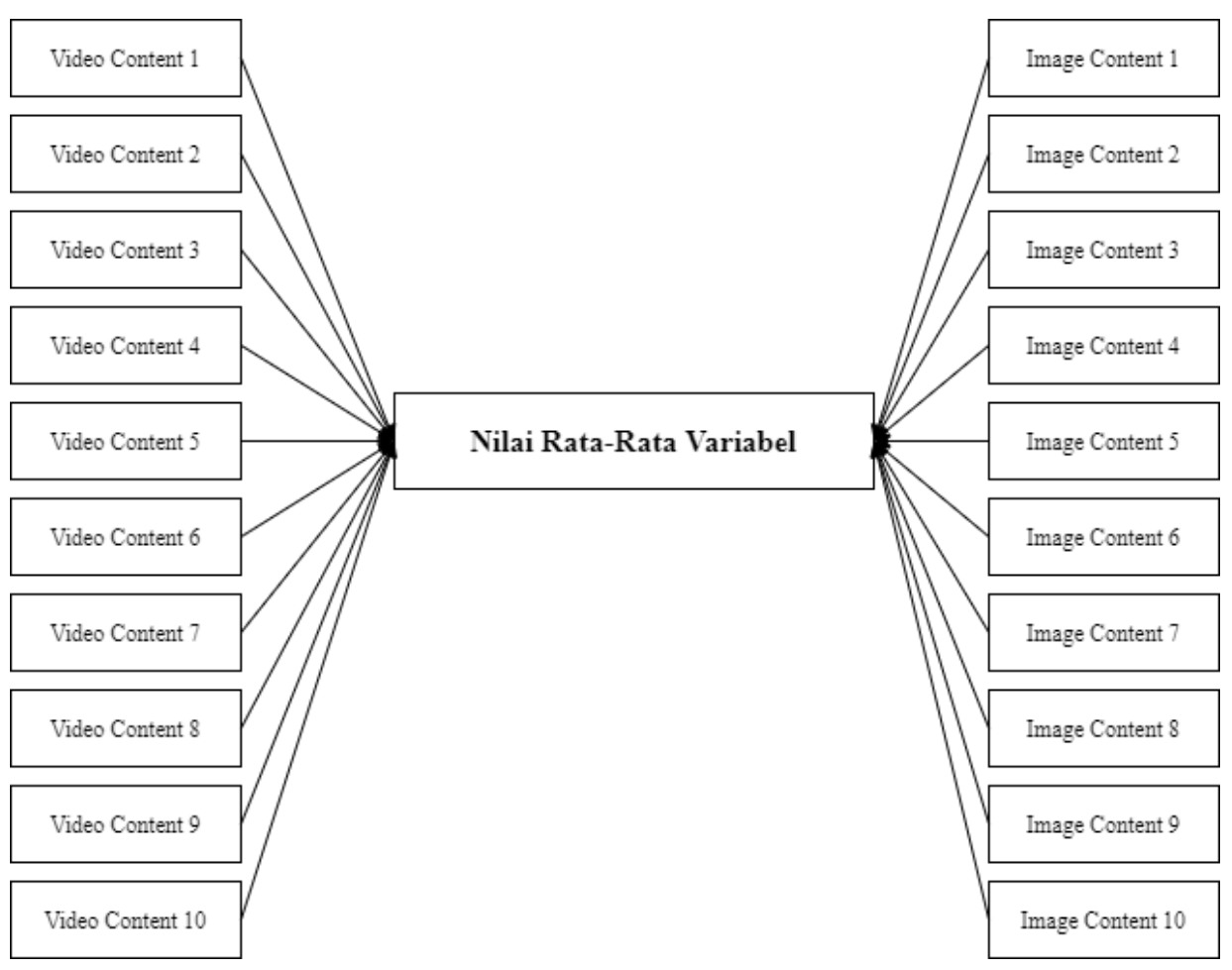

Gambar 1. Analisa Nilai Rata-Rata Variabel.

\section{Menghitung Nilai Kredibilitas Rasio}

Untuk menghitung nilai kredibilitas dari video comments to image comments ratio, peneliti menggunakan cara membagi nilai variabel pertama dengan nilai variabel kedua. Jika video comments memiliki nilai 200 dan image comments memiliki nilai 400 , maka cara menghitungnya adalah $200: 400=0,5$. Dengan begitu nilai dari video comments to image comments ratio adalah 0,5 .

\section{Menentukan Peringkat Pada Akun Instagram}

Untuk langkah terakhir pada penelitian ini adalah menentukan peringkat dalam setiap masing-masing rasio yang ada. Penentuan peringkat perlu memperhatikan karakteristik dari rasio yang di teliti. Jika karakteristik rasio adalah rendah, maka objek yang memiliki nilai terendah akan mendapatkan angka 6 dan objek yang memiliki nilai tertinggi akan mendapatkan angka 1. Tetapi jika rasio memiliki karakteritik tinggi, maka objek yang mendapatkan nilai tertinggi akan mendapatkan angka 6 dan objek yang mendapatkan nilai terendah akan mendapatkan angka 1. Setelah mendapatkan hasil keandalan/kredibilitas ratio, maka kesimpulannya adalah bahwa objek mana yang akan mendapatkan peringkat 1 sampai pada peringkat 6 . 


\section{HASIL DAN PEMBAHASAN}

Akun Instagram dari 6 Penyanyi Indonesia yang Sukses Sebagai Pemain Film, diantaranya :

\section{Maudy Ayunda}

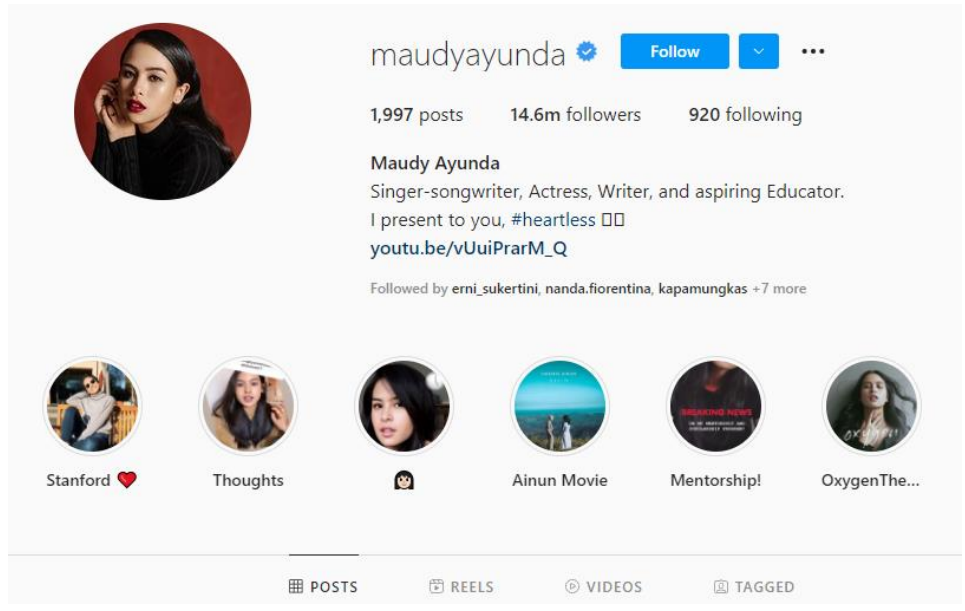

Gambar 1. Akun Instagram Maudy Ayunda

Sumber : https://www.instagram.com/maudyayunda/ (akses pada 21-10-2021)

\section{Iqbaal Ramadhan}

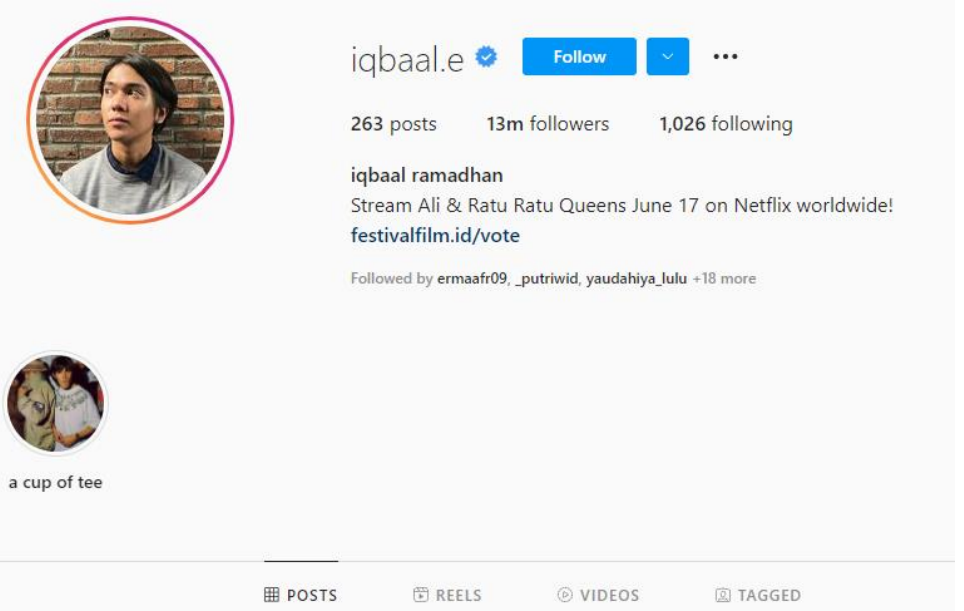

Gambar 2. Akun Instagram Iqbaal Ramadhan

Sumber : https://www.instagram.com/iqbaal.e/ (akses pada 21-10-2021) 


\section{Bunga Citra Lestari}

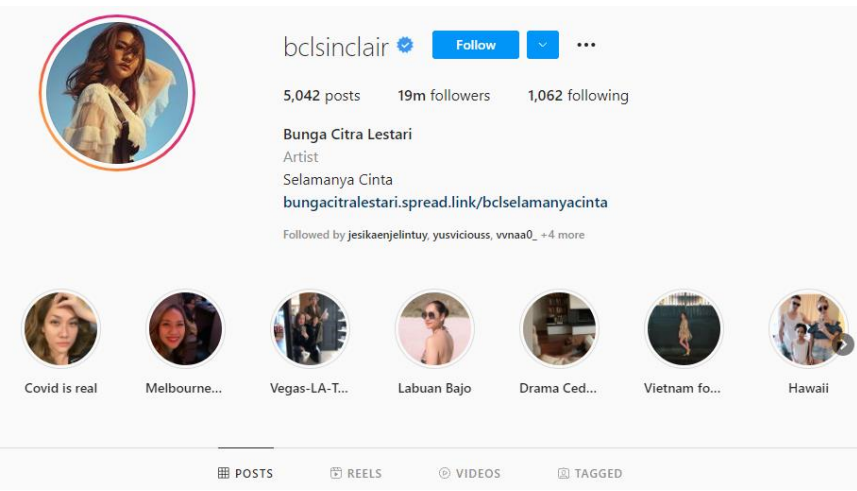

Gambar 3. Akun Instagram Bunga Citra Lestari

Sumber : https://www.instagram.com/bclsinclair/ (akses pada 21-10-2021)

\section{Morgan Oey}

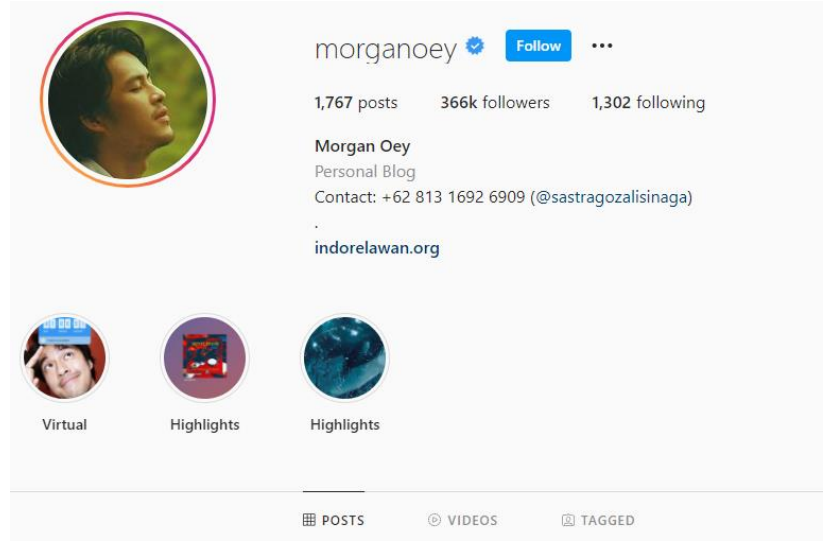

Gambar 4. Akun Instagram Morgan Oey

Sumber : https://www.instagram.com/morganoey/ (akses pada 21-10-2021)

\section{Cinta Laura}

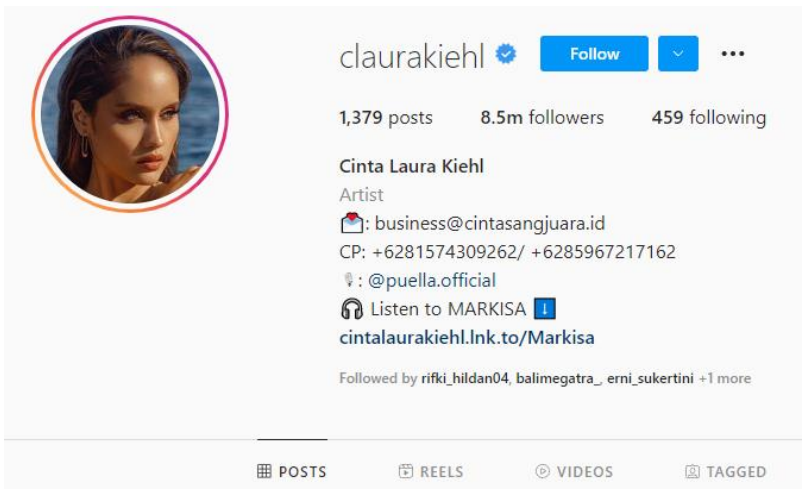

Gambar 5. Akun Instagram Cinta Laura

Sumber : https://www.instagram.com/claurakiehl/ (akses pada 23-10-2021) 


\section{Isyana Sarasvati}

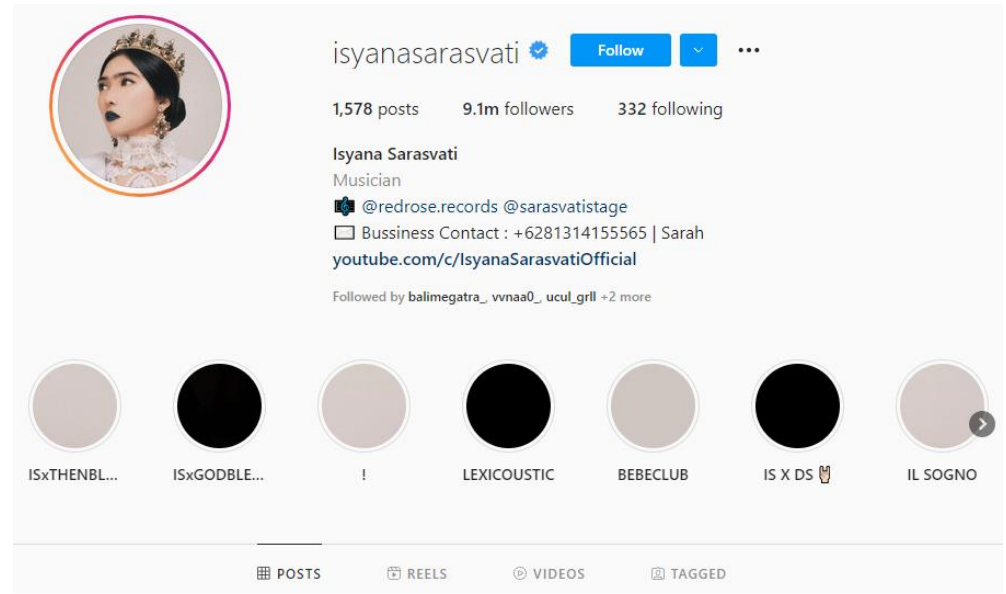

Gambar 5. Akun Instagram Isyana Sarasvati

Sumber : https://www.instagram.com/isyanasarasvati/ (akses pada 23-10-2021)

Dari keenam akun Instagram 6 Penyanyi Indonesia yang Sukses Sebagai Pemain Film, peneliti menemukan nilai dari masing-masing variabel yang ada untuk menghitung rasio Video Comments to Image Comments dari setiap akun. Pada akun Instagram terdapat 7 variabel, diantaranya yaitu :

1. Followers

2. Following

3. Image Likes

4. Image Comments

5. Video Views

6. Video Like

7. Video Comments

Dari ketujuh variabel tersebut peneliti hanya fokus untuk menemukan hasil dari 2 variabel, yaitu :

\section{Video Comments}

2. Image Comments

Dari kedua variabel tersebut kemudian dianalisa sehingga menemukan nilai rata-rata dari variabel video comments dan variabel image comments. Untuk menghitung nilai rata-rata dari variabel video comments dan variabel image comments yaitu dengan cara mengambil minimal 10 postingan kemudian di hitung sehingga menemukan nilai rata-rata dari masing-masing variabel. Berikut merupakan tabel nilai rata-rata dari masing-masing penyanyi Indonesia yang sukses sebagai pemain film, yaitu : 
Tabel 1. Analisa Nilai Rata-Rata Nilai Variabel Video Comments dan Image Comments Akun Instagram Maudy Ayunda

\begin{tabular}{|c|c|c|}
\hline No & $\begin{array}{c}\text { Video } \\
\text { Comments }\end{array}$ & $\begin{array}{c}\text { Image } \\
\text { Commnets }\end{array}$ \\
\hline 1 & 293 & 163 \\
\hline 2 & 185 & 509 \\
\hline 3 & 384 & 522 \\
\hline 4 & 121 & 300 \\
\hline 5 & 86 & 1,288 \\
\hline 6 & 239 & 181 \\
\hline 7 & 749 & 966 \\
\hline 8 & 296 & 903 \\
\hline 9 & 304 & 604 \\
\hline 10 & 1,753 & 165 \\
\hline Total & $\mathbf{4 4 1}$ & $\mathbf{5 6 0}$ \\
\hline
\end{tabular}

Sumber : Pengolah Data Excel

Tabel 2. Analisa Nilai Rata-Rata Nilai Variabel Video Comments dan Image Comments Akun Instagram Iqbaal Ramadhan

\begin{tabular}{|c|c|c|}
\hline No & $\begin{array}{c}\text { Video } \\
\text { Comments }\end{array}$ & $\begin{array}{c}\text { Image } \\
\text { Comments }\end{array}$ \\
\hline 1 & 338 & 592 \\
\hline 2 & 248 & 2,899 \\
\hline 3 & 565 & 1,691 \\
\hline 4 & 1,346 & 674 \\
\hline 5 & 1,404 & 1,636 \\
\hline 6 & 806 & 2,679 \\
\hline 7 & 1,359 & 1,059 \\
\hline 8 & 2,889 & 659 \\
\hline 9 & 717 & 2,447 \\
\hline 10 & 2,244 & 1,635 \\
\hline Total & $\mathbf{1 , 1 9 2}$ & $\mathbf{1 , 5 9 7}$ \\
\hline
\end{tabular}

Sumber : Pengolah Data Excel

Tabel 3. Analisa Nilai Rata-Rata Nilai Variabel Video Comments dan Image Comments Akun Instagram Bunga Citra Lestari

\begin{tabular}{|c|c|c|}
\hline No & $\begin{array}{c}\text { Video } \\
\text { Comments }\end{array}$ & $\begin{array}{c}\text { Image } \\
\text { Comments }\end{array}$ \\
\hline 1 & 302 & 1,574 \\
\hline 2 & 279 & 602 \\
\hline
\end{tabular}




\begin{tabular}{|c|c|c|}
\hline 3 & 3,771 & 281 \\
\hline 4 & 5,864 & 886 \\
\hline 5 & 2,120 & 2,043 \\
\hline 6 & 5,570 & 297 \\
\hline 7 & 2,898 & 398 \\
\hline 8 & 1,097 & 1,235 \\
\hline 9 & 1,571 & 8,207 \\
\hline 10 & 166 & 684 \\
\hline Total & $\mathbf{2 , 3 6 4}$ & $\mathbf{1 , 6 2 1}$ \\
\hline \multicolumn{3}{|c|}{ Sumber : Pengolah Data Excel }
\end{tabular}

Tabel 4. Analisa Nilai Rata-Rata Nilai Variabel Video Comments dan Image Comments Akun Instagram Morgan Oey

\begin{tabular}{|c|c|c|}
\hline No & $\begin{array}{c}\text { Video } \\
\text { Comments }\end{array}$ & $\begin{array}{c}\text { Image } \\
\text { Comments }\end{array}$ \\
\hline 1 & 21 & 26 \\
\hline 2 & 23 & 64 \\
\hline 3 & 24 & 61 \\
\hline 4 & 25 & 27 \\
\hline 5 & 33 & 92 \\
\hline 6 & 48 & 12 \\
\hline 7 & 87 & 96 \\
\hline 8 & 51 & 31 \\
\hline 9 & 53 & 30 \\
\hline 10 & 83 & 6 \\
\hline Total & $\mathbf{4 5}$ & $\mathbf{4 5}$ \\
\hline \multicolumn{3}{|c|}{ Sumber : Pengolah Data Excel }
\end{tabular}

Tabel 5. Analisa Rata-Rata Nilai Variabel Video Comments dan Image Comments Akun Instagram Cinta Laura

\begin{tabular}{|c|c|c|}
\hline No & $\begin{array}{c}\text { Video } \\
\text { Comments }\end{array}$ & $\begin{array}{c}\text { Image } \\
\text { Comments }\end{array}$ \\
\hline 1 & 1,381 & 99 \\
\hline 2 & 2,743 & 193 \\
\hline 3 & 872 & 129 \\
\hline 4 & 1,186 & 510 \\
\hline 5 & 1,102 & 1,399 \\
\hline 6 & 321 & 261 \\
\hline 7 & 847 & 324 \\
\hline 8 & 540 & 576 \\
\hline
\end{tabular}




\begin{tabular}{|c|c|c|}
\hline 9 & 1,610 & 383 \\
\hline 10 & 450 & 570 \\
\hline Total & $\mathbf{1 , 1 0 5}$ & $\mathbf{4 4 4}$ \\
\hline
\end{tabular}

Sumber : Pengolah Data Excel

Tabel 6. Analisa Rata-Rata Nilai Variabel Video Comments dan Image Comments Akun Instagram Isyana Sarasvati

\begin{tabular}{|c|c|c|}
\hline No & $\begin{array}{c}\text { Video } \\
\text { Comments }\end{array}$ & $\begin{array}{c}\text { Image } \\
\text { Comments }\end{array}$ \\
\hline 1 & 204 & 762 \\
\hline 2 & 1,531 & 920 \\
\hline 3 & 176 & 827 \\
\hline 4 & 119 & 103 \\
\hline 5 & 263 & 1,312 \\
\hline 6 & 1,005 & 248 \\
\hline 7 & 808 & 142 \\
\hline 8 & 159 & 144 \\
\hline 9 & 236 & 202 \\
\hline 10 & 279 & 1,173 \\
\hline Total & 478 & 583 \\
\hline
\end{tabular}

Sumber : Pengolah Data Excel

Setelah menghitung nilai rata-rata tersebut, maka akan menemukan hasil akhir nilai rata-rata dari variabel video comments dan image comments.

Tabel 6. Nilai Variabel Pada Akun Instagram 6 Penyanyi Indonesia yang Sukses Sebagai Pemain Film

\begin{tabular}{|l|c|l|c|c|c|c|}
\hline Variable & $\begin{array}{l}\text { Maudy } \\
\text { Ayunda }\end{array}$ & $\begin{array}{l}\text { Iqbaal } \\
\text { Ramadhan }\end{array}$ & $\begin{array}{l}\text { Bunga Citra } \\
\text { Lestari }\end{array}$ & $\begin{array}{l}\text { Morgan } \\
\text { Oey }\end{array}$ & $\begin{array}{l}\text { Cinta } \\
\text { Laura }\end{array}$ & $\begin{array}{l}\text { Isyana } \\
\text { Sarasvati }\end{array}$ \\
\hline Video Comments & 441 & 1192 & 2364 & 45 & 1105 & 478 \\
\hline Image Comments & 560 & 1597 & 1621 & 45 & 444 & 583 \\
\hline
\end{tabular}

Sumber : Pengolah Data Excel

Pada akun Instagram terdapat 14 rasio yang relevan digunakan untuk mengukur kredibilitas pada masing-masing akun. Namun pada penelitian kali ini hanya berfokus untuk menghitung Video Comments to Image Comments Ratio. Untuk menghitung kredibilitas dari masingmasing akun Instagram setiap Penyanyi Indonesia, peneliti menghitung dengan cara : variabel 1 akan dibagi dengan variabel 2 , sehingga ditemukan hasil analisisa dari rasio tersebut. 
Tabel 7. Hasil Perhitungan Rasio Akun Instagram

\begin{tabular}{|c|l|c|c|c|c|}
\hline NO & \multicolumn{1}{|c|}{ RATIO } & $\begin{array}{c}\text { Maudy } \\
\text { Ayunda }\end{array}$ & $\begin{array}{c}\text { Iqbaal } \\
\text { Ramadhan }\end{array}$ & $\begin{array}{c}\text { Bunga } \\
\text { Citra } \\
\text { Lestari }\end{array}$ & $\begin{array}{c}\text { Morgan } \\
\text { Oey }\end{array}$ \\
\hline 1 & $\begin{array}{l}\text { Video Comments to } \\
\text { Image Comments } \\
\text { Ratio }\end{array}$ & 0.78750000 & 0.74639950 & 1.45835904 & 1.00000000 \\
\hline
\end{tabular}

\begin{tabular}{|c|c|}
\hline Cinta Laura & Isyana Sarasvati \\
\hline 2.48873874 & 0.819897084 \\
\hline
\end{tabular}

Sumber : Pengolah Data Excel

Video Comments to Image Comments Ratio memiliki karakteristik yang rendah, artinya semakin rendah nilai yang dihasilkan maka semakin baik kredibilitas dari performa akun tersebut. Untuk memberikan peringkat pada masing-masing Penyanyi Indonesia, peneliti memberikan angka 1 kepada vendor yang mendapatkan nilai tertinggi dan angka 6 untuk Penyanyi Indonesia yang mendapatkan nilai terendah. Berikut merupakan tabel urutan nilai yang dihasilkan oleh masing-masing Penyanyi Indonesia.

Tabel 8. Nilai Rasio Akun Instagram 6 Penyanyi Indonesia Yang Sukses Sebagai Pemain Film

\begin{tabular}{|c|c|l|l|l|l|c|}
\hline \multirow{2}{*}{ RATIO } & \multicolumn{5}{|c|}{ NILAI } \\
\cline { 2 - 7 } & $\begin{array}{l}\text { Maudy } \\
\text { Ayunda }\end{array}$ & $\begin{array}{l}\text { Iqbaal } \\
\text { Ramadhan }\end{array}$ & $\begin{array}{l}\text { Bunga } \\
\text { Citra } \\
\text { Lestari }\end{array}$ & $\begin{array}{l}\text { Morgan } \\
\text { Oey }\end{array}$ & $\begin{array}{l}\text { Cinta } \\
\text { Laura }\end{array}$ & $\begin{array}{l}\text { Isyana } \\
\text { Sarasvati }\end{array}$ \\
\hline $\begin{array}{l}\text { Video Comments } \\
\text { to Image } \\
\text { Comments Ratio }\end{array}$ & 5 & 6 & 2 & 3 & 1 & 4 \\
\hline
\end{tabular}

Sumber : Pengolah Data Excel

Dari Tabel Nilai Rasio Akun Instagram 6 Penyanyi Indonesia Yang Sukses Sebagai Pemain Film dapat simpulkan bahwa Cinta Laura mendapatkan nilai tertinggi untuk rasio Video Comments to Image Comments. Sedangkan akun Instagram Iqbaal Ramadhan mendapatkan nilai terendah untuk rasio ini. Jadi, pada penelitian ini Cinta Laura memiliki kredibilitas performa yang lebih baik dibandingkan dengan Penyanyi Indonesia yang lainnya. 


\section{KESIMPULAN}

Tujuan dari penelitian ini adalah mengetahui kredibilitas performa dari akun Instagram Top 6 Penyanyi Indonesia yang Sukses sebagai Pemain Film menggunakan Video Comments to Image Comments Ratio. Top 6 Penyanyi Indonesia yang Sukses sebagai Pemain Film tersebut, diantaranya : Maudy Ayunda, Iqbaal Ramadhan, Bunga Citra Lestari, Morgan Oey, Cinta Laura, dan Isyana Sarasvati. Dari keenam penyanyi Indonesia tersebut dapat disimpulkan bahwa :

1. Peringkat pertama diraih oleh Cinta Laura dengan nilai tertinggi yaitu 2.48873874 .

2. Peringkat kedua diraih oleh Bunga Citra Lestari dengan nilai 1.45835904.

3. Peringkat ketiga diraih oleh Morgan Oey dengan nilai 1.00000000.

4. Peringkat keempat diraih oleh Isyana Sarasvati dengan nilai 0.819897084 .

5. Peringkat kelima diraih oleh Maudy Ayunda dengan nilai 0.78750000 .

6. Peringkat keenam diraih oleh Iqbaal Ramadhan dengan nilai terendah yaitu 0.74639950 . 


\section{DAFTAR PUSTAKA}

Dahri, Muhammad. 2019. "Jenis Variabel Dan Skala Pengukuran, Perbedaan Statistik Deskriptif Dan Inferensial Dan Statistik Parametrik Dan Nonparametrik." Journal of Chemical Information and Modeling 53 (9): 1-11.

Difika, Fifit. 2016. "Dakwah Melalui Instagram (Studi Analisis Materi Dakwah Dalam Instagram Yusuf Mansur, Felix Siauw, Aa Gym, Arifin Ilham).” Walisongo Respository, 11-36. http://eprints.walisongo.ac.id/6462/.

Hendika Permana, I Putu. 2021. "Analisis Rasio Pada Akun Instagram Untuk Penelitian Kualitatif Menggunakan Metode Ekploratif.” Jurnal Ilmiah Media Sisfo 15 (1): 40. https://www.infoteks.org/journals/index.php/jsikti/article/view/109

Ii, B A B, A Landasan Teori, and Pengertian Pemasaran. 2017. "Analisis Pengaruh Audiovisual..., Ongki Susanto, Fakultas Ekonomi Dan Bisnis UMP, 2017.”

Koltay, András. 2019. "Social Media Platforms." New Media and Freedom of Expression. https://doi.org/10.5040/9781509916511.ch-005.

Mudjiyanto, Bambang. 2018. "Tipe Penelitian Eksploratif Komunikasi." Jurnal Studi Komunikasi Dan Media 22 (1): 65. https://doi.org/10.31445/jskm.2018.220105.

"Multitalenta, 6 Penyanyi Indonesia Yang Sukses Sebagai Pemain Film." n.d. Accessed December 3, 2021. https://www.idntimes.com/hype/entertainment/nur-malika1/multitalenta-6-penyanyi-indonesia-yang-sukses-sebagai-pemain-film/6.

Norhabiba, Fitri, and Ari Ragil. 2018. "Hubungan Intensitas Akses Media Baru Dan Mahasiswa Untag Surabaya.” Interaksi:Jurnal Ilmu Komunikasi 7 (1): 8-15.

Permassanty, Tanty Dewi, and Muntiani Muntiani. 2018. "Strategi Komunikasi Komunitas Virtual Dalam Mempromosikan Tangerang Melalui Media Sosial." Jurnal Penelitian Komunikasi 21 (2): 173-86. https://doi.org/10.20422/jpk.v21i2.523.

Sari, Dian Nurvita, and Abdul Basit. 2020. "Media Sosial Instagram Sebagai Media Informasi Edukasi." Persepsi: Communication Journal $3 \quad$ (1): 23-36. https://doi.org/10.30596/persepsi.v3i1.4428.

Shafita, Rina. 2018. "Studi Deskriptif Kuantitatif Pengaruh Media Sosial Instagram Dengan Minat Wisatawan Terhadap Pariwisata Di Yogyakarta (Studi Kasus Di PT. BKS Tour Services Periode Oktober - November 2017)." Mercubuana Yogyakarta.

Syahadatina, Vionisepti Darahayu. 2018. "BIAS PEREMPUAN DALAM POSTINGAN AKUN INSTAGRAM (Analisis Semiotik Pada Akun Indozonelife).” Eprints Umm 53 (9): 90 . 